short papers will be read: Prof. K. A. Hayes, "Servomechanisms: Recent History and Basic Theory"; Dr. A. Utley, "The Problem of Stabilisa. tion"; and Prof. A. Tustin, "Problems in Control Systems which await Solution". All who are interested in control mechanisms and allied subjects are invited to attend the inaugural meeting. If sufficient response is obtained, the inaugural meeting will be followed by a business meeting to deal with the formation of a control section of the Society of Instrument Technology.

\section{International Conference on Spectroscopy at Radio-Frequencies}

AN International Conference on Spectroscopy at Radio-Frequencies will be held in Amsterdam during September 18-23. The Conference is being organised by the Netherlands Physical Society and supported by the International Union of Pure and Applied Physics. It is intended to have a number of introductory lectures on nuclear, paramagnetic and ferromagnetic resonance and on precision determination of atomic and molecular constants by radio-frequency methods, and these lectures will be followed by discussions. There will be other discussions at the sectional meetings. Further information can be obtained from the secretary of the organising committee, Prof. J. de Boer, Bunsenstraat 98, Amsterdam-0.

\section{Conference on the Physics of Lubrication}

A JOINT conference on the physics of lubrication has been organised by the Manchester and District Branch of the Institute of Physics and by the British Rheologists Club, and will be held in the Physics Department, University of Manchester, during June 29 (2 p.m.)-July I (noon). It is intended to devote sessions to fluid-film lubrication, boundary and extreme pressure lubrication and the physics of lubricants. Suggestions for papers will be welcomed and should be sent, as soon as possible, to the conference secretary, Mr. D. A. Crooks, Imperial Chemical Industries, Ltd., Dyestuffs Division, Hexagon House, Manchester.

\section{Chemical Society: Annual Meeting}

THE annual general meeting of the Chemical Society will be held this year in the King's Buildings, University of Edinburgh, during March 29-30. The presidential address, by Sir Ian Heilbron, will be on "The Chemical Society-a Mid-Century Review", and Prof. G. Hevesy, who has been awarded the Faraday Medal of the Society, will give the Faraday Lecture, his subject being "The Application of Radioactive Indicators in Biochemical Studies". The anniversary meeting of the Royal Institute of Chemistry, to be held in Glasgow, follows on March 31 and April 1.

\section{Royal Society Lectures for 1950}

Royal Society Lectures for 1950 will be delivered as föllows: Croonian Lecture, on June 15 by Prof. F. M. Burnet, director of the Walter and Eliza Hall Institute, Melbourne; Bakerian Lecture, on May 4 by Prof. P. W. Bridgman, Lyman Laboratory of Physics, Harvard University; Ferrier Lecture, on June 29 by Prof. J. Z. Young, professor of anatomy, University College, London; Wilkins Lecture, on December 14 by Prof. F. J. Cole, emeritus professor of zoology, University of Reading. The first Leeuwen- hoek Lecture will be delivered on November 9 by Sir Paul Fildes, director of chemical bacteriology (Medical Research Council), Lister Institute, London; this Lecture was founded in 1948 by a bequest from Mr. George Gabb "for an annual lecture in the field of microbiology".

\section{Seventeenth National Radio Exhibition at Birming- ham}

The Seventeenth National Radio Exhibition will be held at Castle Bromwich, Birmingham, during September 6-16. Since its inception in 1922, this Exhibition, which now includes television, has previously always been held in London (when at Olympia, it has been popularly called 'Radiolympia'), and the move to Birmingham this year is obviously connected with the recent opening of the television transmitter in that city. The Exhibition is being organised by the Radio Industry Council (at 59 Russell Square, London, W.C.1) on behalf of the British Radio Equipment Manufacturers' Association, and Mr. F. W. Perks is chairman of the organising committee, which is substantially the same as for the past two Exhibitions.

\section{Postgraduate Scholarships in Agriculture}

The Ministry of Agriculture and Fisheries and the Department of Agriculture for Scotland propose to award, for the academic year beginning October 1, or earlier, a limited number of postgraduate scholarships in agricultural economies, husbandry, statistics, and agricultural and dairy engineering. The closing date for applications is May 1. Further particulars can be obtained from the Secretary, Ministry of Agriculture and Fisheries (Research Branch), 1-4 Cambridge Terrace, Regent's Park, London, N.W.1, or the Secretary, Department of Agriculture for Scotland, St. Andrews House, Edinburgh, 1.

\section{Announcements}

Prof. E. N. DA C. Andrade, director in the Royal Institution, has been elected correspondant for the Section of General Physics of the Paris Academy of Sciences.

Tue triennial award of the Coopers Hill War Memorial Prize and Medal, which fell in 1949 to the Institution of Electrical Engineers, has been made by the Council to Mr. E. D. Taylor, for his paper on "The Measurement of Inter-lamination Resistance on Varnish-Insulated Sheet Steel for Large Electrical Machines".

The Commonwealth Scientific and Industrial Research Organisation has decided to publish two new journals, the Australian Journal of Agricultural Research and the Australian Journal of Applied Science. These will appear quarterly, and it is expected that four issues of each journal will be published in 1950. Each journal will cost 30s. per annum, or 7s. 6d. per copy. The Journal of the Council for Scientific and Industrial Research ceased publication with Volume 21, No. 4 (November 1948).

Mr. J. W. GRUBER, of the Department of Sociology, Temple University, Philadelphia, writes that he is collecting material referring to the life and work of the nineteenth-century British anatomist, St. George Jackson Mivart. Mr. Gruber will appreciate any information about Mivart, especially concerning unpublished correspondence. 